\title{
Ristipuud maastikul ja usundilises jutupärimuses
}

\author{
Marju Torp-Kõivupuu \\ Valendavad kõrged katused, peidus kuu. \\ Igavesed hinges matused, ristipuud. \\ Nüüd on öö ja kuu, nü̈̈d on süda valus. \\ Henrik Visnapuu, Nüüd on öö ja kuu
}

(Amores, 1919)

\begin{abstract}
Teesid
Ristipuude-traditsiooni uurimisega on siinkirjutaja tegelenud viimased viisteistkümmend aastat. Eesti taasiseseisvumisprotsess ja sellele järgnenud aastad on toonud kaasa arvukalt muutusi nii õigus-, majanduskui ka kultuuriruumis. Kuidas need muutused ja muudatused on mõjutanud-kujundanud pärimusprotsessi, sealhulgas nii kohalike elanike kombekäitumist kui ka teemakohast jutupärimust, millist rolli selles protsessis on mänginud ja mängib meedia ning samuti koha- või koduloo (antud kontekstis siis esmajoones võru keele ja omakultuuri) õpetus nüüdisaegses kooliprogrammis, sellest alljärgnevalt Lõuna-Eesti, LääneSaaremaa ja Põhja-Läti ristipuude-traditsiooni näitel.
\end{abstract}

Märksõnad: ristipuud, matusekombestik, tavaõigus; muinsus- ja looduskaitse, pärandkultuur, meedia, pärimusteadlikkus, rahvapärimus, rahvajutt; memoraat

\section{Sissejuhatus}

Ristipuude-teema Lõuna-Eesti ajaloolise Võrumaa-osa matusekombestiku lahutamatu osana on minu kui uurija jaoks olnud aktuaalne ümmarguselt viimased viisteistkümmend aastat ja sellel teemal on varemalt ilmunud nii (lühi)uurimusi kui ka populaarteaduslikke artikleid (vt lähemalt: Kõivupuu 1996, 1997, 1999, 2000a, 2002; TorpKõivupuu 2003a, 2003b).

Traditsioonikandjate hulka kuuluvana olen ristipuudega seotud oluliselt kauem - Hargla ristipallu ristilõikamist mäletan teadlikult koolieelikuna 1960ndate lõpust, kui maeti minu emapoolset vanatädi. Kui 1980ndate lõpul asusin välitöödel Lõuna-Eestis süsteemselt ka ristipuude kohta materjali koguma, tõdesin, et ristilõikamise traditsioon on siin - erinevalt Põhja-Lätist - üle elanud ideoloogili- 


\section{Marju Torp-Kõivupuu}

selt ja juriidiliselt keerulise nõukogude perioodi ja sulandunud arvestatava tugevusega paikkondlikku luterlikku ja ilmalikku matusekombestikku, säilitades samas ometi teatava, sovetiajale iseloomuliku keelatu-lubatu piiril balansseerimise värvingu. Võõrad, kogukonda mittekuuluvad inimesed ei pidanudki sellest toimingust täit teadmist saama.

Käesolev artikkel baseerub rahvusvahelisel jutu-uurijate kongressil Visbys 2003. aasta augustis peetud ettekandel Cross-trees in belief narrative tradition of South-Estonia and West-Saaremaa Island (Ristipuud Lõuna-Eesti ja Lääne-Saaremaa usundilises jutupärimuses). Artikli käesolevat eestikeelset versiooni on suures osas täiendatud ristipuude-traditsiooni jätkumise või hääbumise seisukohalt olulisest ja hoopis laiemast vaatekohast: usundiliste tõekspidamistega seotud kommete ja tavade jätkumine looduskeskkonnas ehk teisisõnu - kellele de iure ja kellele de facto kuuluvad /on kuulunud pühad puud metsas ja pühad kivid põllul? Kas võime kaasajal tõdeda erinevat lähenemist looduslikku päritolu kultusobjektidele, jaotades nad tinglikult kahte suuremasse kategooriasse:

1) kultusobjektid (sh ka loodus-ja/või muinsuskaitsealused pühad allikad, kivid ja puud vms), mis peegeldavad eestlaste minevikku suunatud passiivset kollektiivset kultuurimälu ning mis tänaseks ei ole enam sisuliselt seotud ühe või teise sotsiaalse grupi aktiivse pärimuse ning kombekäitumisega;

2) kultusobjektid, mis on jätkuvalt seotud ühe või teise sotsiaalse grupi pärimuse ning kombekäitumisega (või on folklooriprotsessi käigus see aktiivne seos taaselustatud) ning milliste objektidega on pärimuskandjatel jätkuvalt aktiivne side ja suhe?

Naastes ristipuude teema juurde, tuli siinkirjutajal 2003/2004. aasta vahetusel tõdeda, et raieküpseks saanud riigimetsade mahavõtmise käigus hävisid osalt teadmatusest, osalt hoolimatusest mitmed Lõuna-Eesti ristimetsatukad (nt Rõuge-Sänna teel asuv metsatukk), ainulaadne osa meie pärandkultuurist, mis praeguseks on oma endisel kujul säilinud ainult siinkirjutaja videomaterjalidel ja fotodel. Lähiajal on muist ristimetsatukki ja ristipuid saanud kannatada muu hulgas ka röövraie käigus, kui tagastatud metsamaade üldjuhul eakad omanikud ei teagi, kus neile kuuluv mets täpselt asub, rääki- 
Rõuge Sänna ristimets detsembris 2003, ristipuu on tähistatud lindiga. Marju Kõivupuu foto.

mata sellest, mis seal täpselt kasvab või millised omakultuuri seisukohalt olulised mälestusmärgid seal asuvad. Nn tankistide ees on tänases Eesti Vabariigis kaitsetud ka (loodus)kaitsealused metsad ja muud pärandkooslused.

Pühad puud või puudesalud maastikul ja nende saatus aktiivse majandustegevusega aladel tekitas ka massimeedia huvi ristipuude saatuse vastu, samuti kui kohaliku rahva ehk siis teisisõnu - traditsiooni-

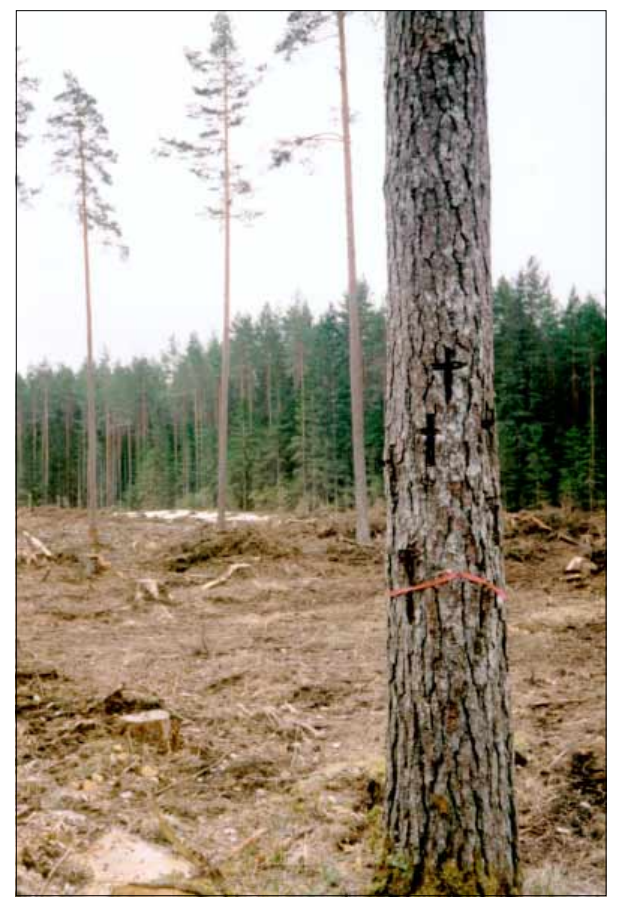
kandjate suus aktiveerus ristipuude-teemaline jutupärimus. Kõik ristipuudega ja ristipuude ümber toimuv on üks värvikas näide folklooriprotsessist, mille seesugust kulgu ei osanud kümmekond aastat tagasi prognoosida ei siinsed ega Lääne uurijad (vt Vilkuna 1991; Vilkuna 1992; Kõivupuu 1997).

Eeltoodust lähtuvalt püstitaksin järgmise küsimuse: kas võime ristipuude traditsiooni näitel tõdeda, et folklooriprotsessi suunavateks-mõjutavateks teguriteks võivad olla aktiivsetest pärimuskandjatest sageli sõltumatud tegurid, nagu seda konkreetsel juhul on näiteks maa- või metsaomandi kuuluvus ja sellest tulenevad tagajärjed?

Sellelegi küsimusele püüab ristipuude näitel käesolev artikkel mõningast vastust anda. 
Marju Torp-Kõivupuu

\section{Ristipuud ja ristimetsatukad - osa metsa- ja rahvausuga seotud pärandkultuurist}

Eestlased on põliste metsaelanike järeltulijad. I aastatuhandel $\mathrm{eKr}$ levima hakanud maaviljelus toimus suuresti metsa arvel. Alates nooremast pronksiajast (1100-500 eKr), mil siinmail hakati rajama esimesi põlispõlde (nn balti põllud), taganesid järk-järgult puud inimasulatest kaugemale. Mets polnud enam põlise elatuse andja, polnud enam nii intiimne ja lähedane kui eelnenud aastatuhandetel (Ränk 1996; Paulson 1997; Viires 2000 jpt). Talust saab peamine asustusüksus ja siinsete asukate jaoks muutub tähtsaks maaomandi mõiste. Maaomandi peamiseks õigustuseks on kõikjal ja kõikidel aegadel olnud selle põlisus. Selle tõestuseks olid/on tõelised või väljamõeldud esivanemate kalmud. Ja kuigi valdavalt agraarse eluviisi tõttu mets ja metsaelu inimestest on aastasadade jooksul üha kaugenenud, on puud ja metsad säilitanud siinsete inimeste elus emotsionaalse ja rituaalse väärtuse tänini, kõnelemata puhtpraktilisest tähtsusest (Kaasik 2004; Torp-Kõivupuu 2003a; Torp-Kõivupuu 2003b jpt. $)^{1}$

Pühad metsatukad (pühad hiied) ja pühad (põlis)puud on osa meie rikkalikust pärandkultuurist. Sõna "pärand" kasutamine sellises tähenduses ei ole eriti vana. Algselt on sel sõnal olnud üks, juriidiline tähendus - see on miski, mis on saadud pärimise teel, miski, mis on päritud (näiteks testamendiga). ${ }^{2}$ Pärandkultuuri võib käsitleda kui erinevate põlvkondade elu ja tegevuse jälgi maastikul, mille ainelised ilmingud on aga tihedalt seotud nii omavahel kui ka rahvakultuuri vaimse pärandiga. Vanad ehitised, muistsed metsa- ja taliteed, lubjaahjud, tõrvapõletuskohad, pärimustega seotud puud ja kivid, kadunud külade põlispuud, kohanimed ja paljud teised loendamatud mälestised seovad rahvast oma isamaa ja emakeelega. Vaieldamatult on pärand(kultuur) kindlasti ka poliitiline valik minevikust - see on väärtustav valimine, kusjuures objekti või nähtuse vanus ei ole sugugi alati millegi pärandkultuuri tuumiku hulka arvamisel otsustav (vt ka Lauri Honko määratlust tuumikfolkloori kohta - ainult see, mida ühiskond väärtustab minevikust (jutustavas) pärimuses, on tuumikfolkloor). Näiteks peame me pärandiks pigem tuliuusi või restaureeritud paarisaja aasta taguseid taluhooneid kui nõukogude ajast ehk siis lähiminevikust pärit kolhoosilautasid; folkloriste ja koduloo-uurijaid näib huvitavat pigem vanem (koha)päri- 
mus, mis on talletatud arhiividesse, mitte nii väga teemad, mis on seotud lähimineviku või olevikuga jne. Siit omakorda võiks tõstatada küsimuse - kui vana traditsioon on piisavalt vana, et seda võiks pidada traditsiooniks? Kuid selle küsimuse üle arutlemine kaugeneb käsiteldavast teemast juba oluliselt.

Tänases ühiskonnas on kultuuripärandi kaitse seotud küsimustega pärandkultuuri ja muinsuskaitse vahekorrast. Muinsuskaitseobjektid on üldiselt küll kõik pärandkultuuri objektid, aga enamik pärandkultuuri objektidest ei kuulu praegu ega ilmselt ka tulevikus muinsuskaitse alla - sinna kuulub väärtuslikum osa pärandkultuurist. Samas on väärtuslikuks ja mitteväärtuslikuks jaotav suhtumine ise kaheldava väärtusega - kas olemasolevate väärtuste väärtustamiseks tuleb oodata nende kadumist või hävimist? ${ }^{3}$ Ja kas kultuuripärandi väärtuslikkust on kutsutud ja seatud määratlema ja hindama vaid ühiskonna n-ö "paremad inimesed" - etnoloogid, folkloristid, ajaloolased, muinsuskaitsetegelased jne - või on võimalus sõna sekka öelda ka traditsioonikandjatel endil?

Võrdluseks võib tuua Rootsi näite, kus on pikad traditsioonid mittekaitstava pärandkultuuri inventeerimisel ja säilitamisel. Algust tehti sellega 1970. aastatel ja tänaseks on lisaks metsaorganisatsioonidele kaasatud projektgruppidesse arheoloogid, kultuuri- ja muinsuskaitsetöötajad, kuid pärandkultuuri kaitse efektiivsus ja haare oleneb peaasjalikult kohapealsetest entusiastidest, kellel on olemas toeks riiklik otsus ja finantseerimine (http://www.hot.ee/ letarang/kaitsestmetsas.htm).

Eestis on tänaseks võimalike pärandkultuuri kaitsealuste objektide hulka teoreetiliselt arvatud lisaks kultuurmaastiku kujunemisega seotud muististele ka ehitised ja rajatised, majandusega seotud mälestised, militaarsed mälestised, looduslikud ja poollooduslikud ning pärimustega seotud mälestised (kaheksa alarühma, nende hulgas eraldi real hiiekohad, hiiepuud, pühad puud, ristimäed ja ristipuud) (http://www.hot.ee/letarang/kaitsestmetsas.htm).

Ristipuud Kagu-Eesti pärandkultuuri osana on usundiliselt mõneti marginaalne nähtus. Et ristipuud ei kuulunud otseselt etnograafia valdkonda, puudus pikka aega ka kodueesti etnograafia-alastes teatmeteostes ristipuu (ristipedaja, ristikuuse) märksõna (Hiiemäe $e t$ al 1993) või käsitleti ristipuude traditsiooni minevikunähtusena (Ränk 1995: 180-181) või paiguti tänini tuntud lokaaltraditsioonina (Viires 1995: 237-238 viitega Vilkuna 1992: 54-58; Viires 2000: 248 viitega Kõivupuu 1997: 35-61; Vilkuna 1992: 54-58). 
Marju Torp-Kõivupuu
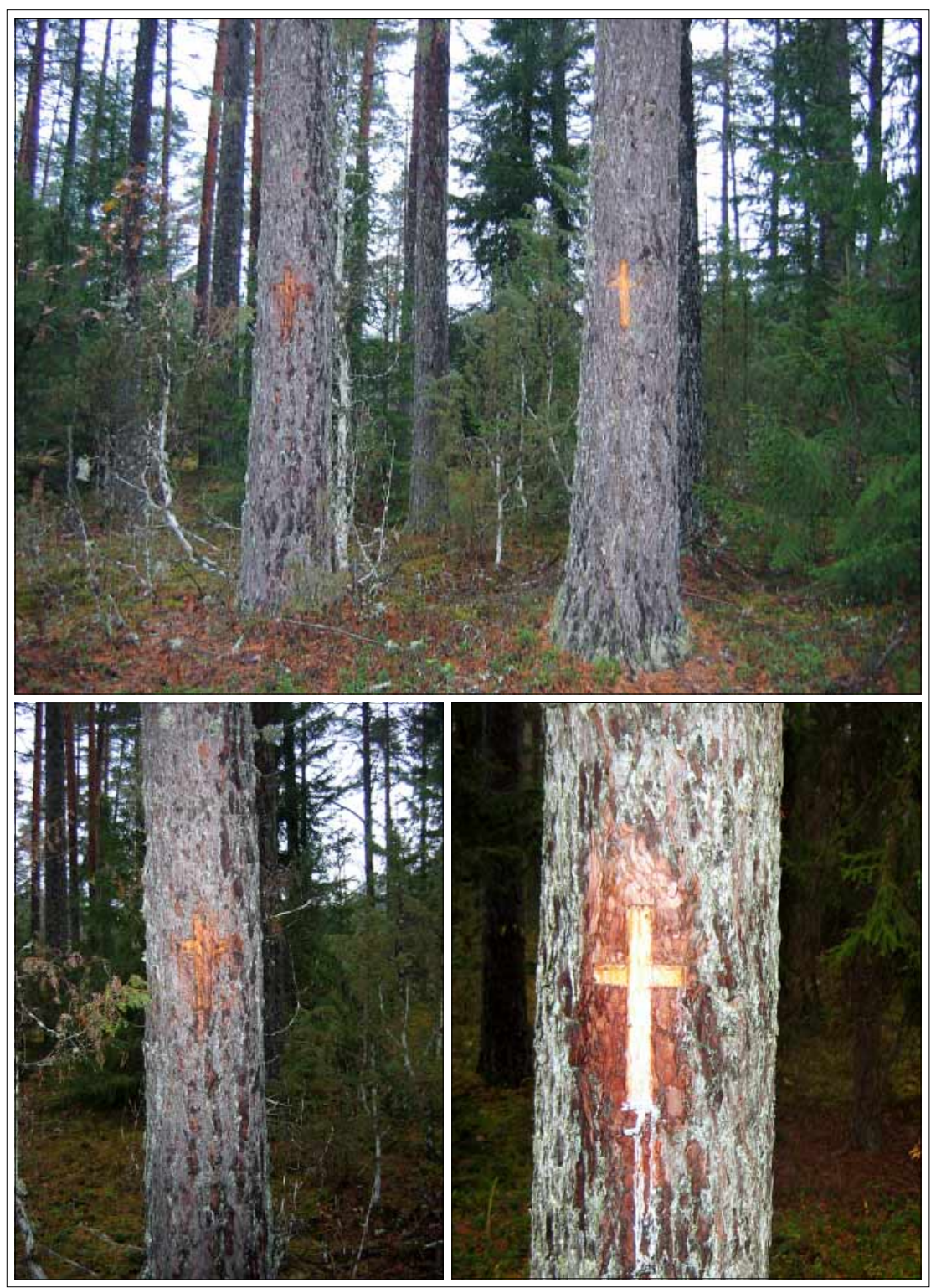

Saru ristimets, oktoober 2004. Marju Kõivupuu foto. 
Ristipuude fenomenis on konserveerunud ürgvanad üldlevinud arusaamad siirdhingest ja puust kui hinge asupaigast (vt Torp-Kõivupuu 2003b: 91-125). Tõenäoliselt tulebki puusse risti lõikamise traditsiooni algupära otsida eelkristlikust animistlikust perioodist, kus surnute hauatagust elu kujutleti varasema elu jätkuna selles metsas, kuhu laibad jäeti või hilisemal ajal ka maeti. Metsa, kuhu maeti esivanemad, hakati pidama pühaks. Pühad hiied on seega algselt olnud ilmselt matusepaigad ja uskumuse kohaselt elasid hiiepuudes lahkunute hinged edasi. Traditsioonilistes kultuurides usuti lahkunu hinge siirdumist looduslikku objekti (puusse, kivisse, allikasse), mida peeti pühaks. Seeläbi said need erilise jõu, neile omistati arstimisvõimet, nad võisid liikuda kohast kohta, neile toodi ohvriande. Surnutekultuse muutudes tekkis kujutelm väljaspool surnukeha elavast hingest, kes mõningatel juhtudel võis olla pahatahtlik (eriliselt surnud inimese hing, nõia hing), ajapikku hakati kartma halba kõigilt surnutelt. Eesti usundis ei pääsenud hing manalasse, kui surnule polnud ohverdatud (Kulmar 1994: 58). Seepärast tuli surnute hingi mälestusohvritega lepitada ja tõrjemaagiliste toimingutega tõkestada nende tee matusepaigalt koju. Varasemal ajal riputati mälestusohvrina puu külge värvilisi lõngu ja paelu, seejuures joodi suutäis viina. Ristiusu levides kinnistus kurja tõrjevahendina ristimärk ning süvenes uskumus, et kodukäija ristist mööda minna ei saa (Vilkuna 1991: 54-58; Viires 1995: 237-238). Sellest teooriast lähtuvalt võib ristipuid käsitleda ka kui hiiepuid ja ristimetsatukki vaadelda kui tänaseni säilinud pühasid hiisi, kuhu on kinnistatud lahkunute hinged.

Kuigi ristilõikamise traditsiooni võib tänapäeval tõlgitseda ka kui kristlikku toimingut (Vilkuna 1991: 10), ei kuulu tava kiriklike matusetalituste hulka, pigem vastupidi. Ristimärgi lõikamine okasvõi lehtpuusse traditsioonilise matuserituaali osana teel kalmistule ei kuulu ei ortodoksse ega ka luterliku kiriku agendas sätestatud kombetalituste juurde. Enamike Lõuna-Eesti maakoguduste õpetajad seda kommet siiski aktsepteerivad, põhjendades seda surnu ja tema lähedaste viimase soovi austamisega. Osa selle maanurga kogudustesse väljastpoolt teenima tulnud pastoreid on siiski risti puusse lõikamise tava kristliku matusetalituse osana tauninud ja nende eest on toimingut sageli isegi varjatud. Praegune Hargla koguduse diakon E. Kollom ja Rõuge Pindi koguduse endine õpetaja Laine Villenthal on öelnud siinkirjutajale, et nad ei ole vastu, kui leinajad on otsustanud ristilôikamise traditsiooni järgida, kuid nende isikliku 


\section{Marju Torp-Kõivupuu}

seisukoha võib kokku võtta E. Kollomi sõnadega: "Ega see nüüd midagi juurde ka ei anna" (Torp-Kõivupuu 2003b).

Ristilõikamise traditsioonil ei tohtinuks teoreetiliselt kohta olla ka ateistlikust vaimust kantud nõukogudeaegsel (pool)ilmalikul matusel, seda enam, et sellesse traditsiooni kui - NB! kristlikku kombesse - suhtusid halvustavalt nii kohalikud kui ka mujalt sissetulnud nõukogude juhtivtöötajad (parteisekretärid, ateistlikust vaimust kantud kooliõpetajad jne). Kui leinajatel oli võimalik, lõigati rist puusse nõukogude võimu poolt võõrandatud kodutalu piiril, väljendades selle toiminguga iseoma põliste traditsioonide austamist ning sõnatut protesti vägivaldse ja võõra ühiskonnakorralduse vastu. Ka on ristilõikamise rituaal nõukogude perioodil traditsioonikandjate endi arusaamade kohaselt teinekord kompenseerinud kristliku matusetalituse puudumist, mida erinevatel põhjustel polnud võimalik lahkunule korraldada (Torp-Kõivupuu 2003b).

Nõukogude perioodil paiknesid praeguseks teadaolevad ristimetsatukad riigile kuuluval territooriumil. Osa suuremaid ristipuid (nt Laatre ristipedajas, Mustahamba ristitamm jpt) oli võetud riikliku looduskaitse alla. Ametliku kaitseta olid ristimetsatukad. Ristipuude või ristimetsatukkade langetamist on ette tulnud küll aktiivse majandustegevuse käigus. Sastavi ristimets Urvaste kihelkonnas jäi maantee laiendamisele-õgvendamisele ette 1990. aastatel; 1997. aasta suvel langetati Kanepi kihelkonnas lageraiet tehes ka ristipuudetukk; Saru-Hargla ristipalu harvendasid omaaegse üleliidulise alluvusega Saru lauatehase hutsuulidest ja ukrainlastest metsatöölised jne. Need on vaid mõned, autorile seni teadaolevad näited.

Möödunud sajandi 30.-40. aastateni on ristilõikamise traditsioon matusekombestiku osana olnud elujõuline ka Lääne-Saaremaal Kihelkonna kihelkonnas, kus ristimärgile lisaks lõigati puusse ka peremärk, mis muutis ristipuu kohalike elanike jaoks oluliselt informatiivsemaks. Tava hääbus Saaremaal ühelt poolt kindlasti seetõttu, et sealsed ristimetsatukad jäid majandustegevusele ja teede laiendamisele ette ning inimestel puudus rituaali sooritamiseks harjumuspärane ja sobilik koht. Teiseks tõenäoliseks - ja ilmselt olulisemakski traditsiooni hääbumise põhjuseks võib arvata seda, et kohalike elanike jaoks oli kaotanud ristide lõikamise tava matusekombestiku osana oma sisulise ja tähendusliku funktsiooni (vt ka Honko http://haldjas.folklore.ee/tagused/nr6/honko.htm). LõunaEestist on aga samast ja oluliselt hilisemastki ajast teada, et kui metsatukk, kuhu oldi harjunud mälestusriste lõikama, tuli maha 
võtta, leiti läheduses uus, sobilik puudesalu ja traditsioon jätkus oma harjumuspärasel, sissejuurdunud moel (Torp-Kõivupuu 2003b: 91-125; Kaido Kama suulised teated 2004. aasta talvel siinkirjutajale).

Ristilõikamise traditsioon oli tuntud suhteliselt hilise ajani ka Põhja-Lätis (Vijcieme, Smiltene, Trikata ümbrus), mis on olnud ajalooliselt nii põhjalätlaste kui ka lõunaeestlaste asuala ning enamvähem kuni Eesti Vabariigi sünnini 1918. aastal ühine kultuuriruum - Liivimaa. Ka lätlaste matusekombestikku on ristilõikamise rituaal kinnistunud kristliku varjundiga toiminguna: kalmistuteelt tulles on ristimärk puutüvesse lõigatud põhjendusega, et surnu leiaks viimsel kohtupäeval tee koju. Rist puul osutanud ka sellele, et seda teed on kalmistule viidud kristlane. Kui lahkunu oli naine, lisati ristimärgile riideribasid (Valka lähedal tehtud koguni kangaribadest lillekimbuke) ning kollaseid ja punaseid lõngu. Ristilõikamise juures joodi õlut või samagonni, viimast piserdati ka maha ning järele jäänud õlu ohverdati puu juurtele (Vilkuna 1992: 58).

Vidzemest pärit kirjaniku ja ajaloolase A. Goba andmetele tuginedes saan lisada täiendavalt järgmist:

Kõige sagedamini kasutati [risti lõikamiseks - M. K.] pühi mände, harvemini teisi puid. Kui matuselised sõitsid kalmistult koju, peatusid nad tavaliselt teeäärse püha männi (või kuuse) juures, loikasid puu koorde risti, harvemini ka aastaarvu ja kuupäeva. Seda tehti maagilistel eesmärkidel - et surnu ei tuleks koju tagasi ja ei tülitaks elavaid.

Smiltene lähedal kasvas kunagi vana mänd, mis kuivas ära sõjajärgsetel aastatel Ka selle männi juures peatusid sageli matuselised, lõikasid puu koorde risti, aga mõnikord pidasid isegi väikese söömingu - võtsid veidi toitu ja napsi. Sellist pärimust tean Smiltene ja Trikata ümbrusest, aga see traditsioon on tuntud ka mujal Lätis (A. Goba kiri M. Kõivupuule 30.03.1995).

Põhja-Lätis hääbus komme nõukogude perioodil, mil traditsiooni järgijaid karistati - metsamajandite ametnikud trahvisid inimesi riigivara tahtliku kahjustamise eest:

Rist puu pääle? See on lätlastel ka. Vaat see koht, kus mina sündisin, see on siit [Valgast - M. K.] umbes $400 \mathrm{~km}$, Nereta rajoonis [Nereta rajoon asub Läti lõunaosas Leedu piiri ääres - 


\section{Marju Torp-Kõivupuu}

M. K.]. Sääl ka lõigati riste puukoorde. Aga metsamajand trahvis puude rikkumise eest. Mina küll ei leia, et see on puude rikkumine... See koht oli surnuaia lähedal. Riste tehti ka salajas (60-aastane Kaagjärves (Karula khk) elav lätlasest meesinformant M. Kõivupuule 1998. aasta detsembris).

Tänapäeval on Põhja-Lätis siiski ristilõikamise traditsioon paiguti taaselustunud, kuid ristide puusse lõikamist matusetalituse juures tuleb siiski pidada pigem harvaks erandiks kui levinud kombeks.

Naastes Lõuna-Eestisse, meenutagem sedagi, et 1980ndate lõpul hoogustunud nn Võru liikumine ${ }^{4}$ pööras muu hulgas senisest enam tähelepanu omakultuuri erinevatele ilmingutele kui ka teatavas mõttes legaliseeris ja väärtustas mitmeid marginaalseid kohalikke kombeid ja tavasid. Varasemast erineva, avalikult positiivse tähelepanu alla sattusid ka ristipuud kui kaitsealused loodusobjektid või rahva enda poolt pühaks peetud puud, mis vajaksid ametliku kaitsealuse staatust. Võru keele ja kohaliku kultuuriloo õpetamine suurendas kooliõpilaste - ja küllap kaudselt nende vanemategi - pärimusteadlikkust: muu hulgas juhtis tähelepanu ka ristidega puudele ja avas nähtuse semantikat. 2001. aastal Võru Instituudi poolt üllitatud koolilaste auhinnatud võrukeelsete kirjatööde kogumikus "Mino Võromaa" leidub Mõniste Põhikooli 3. klassi õpilase Marilin Mõttuse lugu ristipuudest, mida illustreerib Võru 1. Põhikooli 9. a klassi õpilase Inga Antsoni joonistus (Mõttus 2001: 26-27).

Pärimusteadlikkuse illustratsioonina võib tuua veel sellegi, et mõnede kohalike valdade ajalehed on viimasel kümnendil kasutanud leinakuulutuste rubriigi päisena sageli fotofragmenti mõne ristipuu tüvest, millele on lisatud temaatiline regivärsikatke.

On meenutamisväärne, et mitmed kombed ja uskumused, mis on olnud seotud pühade hiitega, tõenäoliste kunagiste matusepaikadega, on kandunud üle meie kalmistukultuuri - ka kalmistul kasvavate puude oksi põhjuseta ei murta; kalmistult ei tooda tõrjemaagilistel eesmärkidel kunagi midagi koju kaasa jne. Kunagiste pühade metsade (hiite) hävitamise üheks tõenäoliseks põhjuseks võiks arvata ka ristiusustajate soovi sundida sel moel siinseid põlisasukaid matma surnuid ristiusu kommete kohaselt kristlikult pühitsetud mulda ja võtma omaks kristliku surmakontseptsiooni.

Siiski on ajaloolisel Võrumaal tänini säilinud üksikuid perekonnakalmistuid, mille tekkeaeg jääb küll esimese Eesti Vabariigi algusse. 
Selliste pühapaikade tekkepõhjuseks on sageli olnud kas kogukonnasisesed tülid või talumehe siiras soov puhata igavest und päris oma maa peal - niipal'lo piat õks maad olõma, kohes hinnäst matta saat (Saar 2004). Sel juhul on kodusurnuaed ka vaimuliku poolt pühitsetud. Sõukandite nn taarausu-kalmuaia tekkepõhjuseks on olnud pere vaesus, pole suudetud kirikule vajalikul määral maksu maksta ja pere löönud kirikust lahku: a õks es olõ tuu lahkulüümine nii kah, et nü̈̈d om mi pere taarausku. Ma olõ esiki leerin käünü (Saar 2004; Torp-Kõivupuu 2003b: 151).

Pean siinkohal märkimisväärseks, et enamik tänaseid noori maa- ja taarausulisi oma hiiekäsitluses kas teadlikult või alateadlikult surma- ja matusetemaatikat väldib, ${ }^{5}$ piirdudes hiie mõiste avamisel pelgalt tõdemusega, et hiis on mõiste põliskultuurist, üks kogukondlik polüfunktsionaalne pühapaik, millesse alates 19. sajandist on siinne elanikkond suhtunud hoolimatult (Kaasik 2004: 1217). Samas näiteks Aleksander Heintalu (Vigala Sass) aga lähtub püha hiie ja hiiepuude semantika avamisel peaasjalikult just surmaja matusetavadest ning loob seoseid ka kristlike kommete (rist puusse) ja eelkristlike uskumuste vahel (Heintalu 2001: 255-257).

Lihtsustatud ja neomütoloogilise varjundiga hiite kui püha metsa fenomeni avamine kajastub selleski, et võimalike matusepaikadena kunagistes hiiekohtades aktsepteeritakse vaid kalmete olemasolu (Remmel 1998: 17 viitega Anttosele ja arheoloog H. Valgu tähelepanekutele). Uuemad teooriad arheoloogia vallast aga väidavad, et ka Eesti territooriumil pole välistatud ei õhku ega vette matmised, mille kohta, arvestades laiba kohtlemise spetsiifikat, on puudulikult leide või puuduvad leiud hoopis, ja oletusi saab teha üksnes esiajalooliste asukate asustuspilti, täpsemalt asulakohti, uurides (Kriiska \& Tvauri 2002: 61-62). Ka sõna hiis etümoloogia avamine pelgalt eriliselt püha paiga tähenduses (Remmel 1998:15) pole keeleajalooliselt ja semantiliselt ehk päriselt ammendav - Väike murdesõnastik pakub kõnealuse sõna vasteks mets (VMS I: 88); Wiedemannil leiame hiz vastena hein, võsa (Wiedemann 1973: 143); Saareste seletussõnaraamatust leiab märksõna mets alt ka hiie (hiis, hiid) - metsasalu, väheldane mets, pühitsetud metsatukk, pühaks peetud metsatukk, kuid see sõna pole Eesti murretes ja murrakutes üldtuntud (Saareste 1959: 884; 1263). Soome keeles on sõnal hiisi koguni kaks vastakat ja sealjuures eriti intrigeerivat tähendust - 'püha metsasalu' ja 'põrgu' (vrd: painu hiiteen! = käi põrgu!) jne. 
Marju Torp-Kõivupuu

\section{Ristipuud usundilises jutupärimuses}

\section{Ristipuud ja rahvapärane tervendamine}

Usk püha risti tervistavasse ja päästvasse jõudu kestab inimeste hulgas tänapäevani. Ajaloolise Võrumaa inimesed on ristipuude juurest otsinud abi erinevate tervisehädade puhul ja on enda sõnutsi seda ka saanud, eriti sellisel juhul, kui tervisehäda põhjustajaks peetakse mõnda surnud sugulast või tuttavat. Surnud esivanemate poolt saadetud haigused on üks rahvapäraseid haiguste võimalikke liigitusi (Kopponen 1973; Kõivupuu 2000b:134-135). Kuigi LõunaEesti elanikkonna seas tänini levinud arusaamade hulgas tervisehädade tekkepõhjustest praktiliselt puuduvad uskumused vahetult surnud esivanema(te) poolt saadetavatest haigustest, pole harvad kujutelmad psüühilise taustaga haigustest, mille peapõhjuseks on surnuhirm või surnust ehmumine (Kõivupuu 2000b: 134-135). Surnu ehmumisest põhjustatud haiguste arstimine põhineb kontaktmaagilisel ravivõttestikul. Hinnatud ravivahenditeks on peetud surnupesuseepi või -viina, surnu riideid, samuti liiva, mida on toodud kas kalmult või surnu hinge asupaigast - ristipuu juurest (Kõivupuu 2000b: 20-21). Sellised narratiivid ringlevad peamiselt perekonnasiseselt, neid jutustatakse kas isikukohaselt ( $\mathrm{nn}$ minuga, jutustaja (patsiendi) endaga juhtunud lood) või siis jutustaja vaatekohast edastatakse lähisugulaste pärimust. Tüüpiline rahvapärasele tervendamisele on neis narratiivides seegi, et tervendamisest saab hädaline teada alles kunagi hiljem, näiteks täiskasvanu- või raugaeas, kus pole enam karta, et see või teine surnuehmatuse-tõbi pöördub tagasi.

Isä suri mul ära, ma kartsin tedä väega, ku ta surnu olli. Ma nakse tedä unes nägemä. Terve aasta, iga öö. Imä läts sis küläarsti manu', see ütli, et mine selle risti juure, mis esäle puu sise tettü om, ja võta säält liiva ja pane voodisse. Minä es tiädnü, et imä mind nõnna ravis. Kaesin iks, et mis tuu säng nii liiva täüs om. Hädä kadus är'. Sis mitme aasta päräst ütli imä, et timä tõi sedä liiva (EKRK I 92, 141 (10) < Rõuge khk (1992)). 
Marju Torp-Kõivupuu

\section{Põhjus-tagajärg (tegu-karistus) skeemi järgivad usundilised hoiatuslood}

Lõunaeestlaste eetiliste ja usundiliste arusaamade kohaselt ei murta ristipuudelt oksi ja neid puid ei langetata. Kes reeglite vastu kas teadmatusest või meelega eksib, seda tabab õnnetus, ehk siis teisisõnu - surnud esivanemate poolt saadetud karistus, mida enam rahvapäraste võtetega pole võimalik parandada, või on tagajärg sootuks fataalne - puudelangetaja saab mingite juhuste kokkulangemise tõttu ise surma.

See oli vast 1987. aastal Viirapalus [Rõuge khk põhjaosa M. K.]. Kõige tõenäolisem on, et kuna metsavahi maja taga on see ristimetsa tukk - kuused põhiliselt... Seal ta seda metsaalust puhastas, kuusk on kerge kuivama ja eks ta mõne maha võttis. Tema oli Võru linnas üles kasvanud eestistunud venelane, eesti keelt ta ei rääkinud, võru keelt küll... Seda tausta ta vist ei saanud teada, hiljem jutuajamises sai ta kusagilt teada, et risti tähendus on see... 1988. aasta talvel, kuna see suur tuulemurd oli... ta jäi metsas puu alla ja sai surma. See ristipuude lõikamise asi tuli ka ühises jutuajamises välja, et miks neil puudel ristid peal on. Ega ta eesti kultuurist midagi ei teadnud. Aga see, mis temaga juhtus seal tuulemurrus, oli muidugi ka tema enda viga, ta laskis puu endale ise peale (anonüümne informant Marju Kõivupuule 1996).

Kuuske [ristikuuske - M. K.] ei tohtivat maha lõigata, siis tulevat lõikajale suur häd ä (ERA II 282, 43576 (14) < Tarvastu khk (1940)).

Kuulsin, see oli vist Saatse kandis. Ühele sovhoosi funktsionärile ei meeldinud rahva talitused lautsipedaja man. Kuna ta ei leidnud kedagi, kes käsu korras oleksid selle puu maha võtnud, võttis ta asja ise käsile. Räägitakse, et mehel olevat peale seda käed ära kuivanud... (A. Kikkas M. Kõivupuule 15.03.2004). 
Marju Torp-Kõivupuu

\section{Intensiivset üleloomulikkuse kogemist edastavad memoraadid}

Harvades memoraatides kirjeldatakse ristipuude läheduses kogetud ebameeldivaid elamusi (kummitelu) või siis kardetakse sõnulseletamatu hirmu ajel ristipuudest mööduda.

Praeguse Kiirassaare küla piirkonnas Oitma põllu käänu juures olid jämedad männid, kuhu lõigati riste, mis pidid surnute hinged kinni hoidma. Kui matuserong oli mööda läinud, loikas üks matuselistest koore sisse risti. Seda kohta kardeti ouddsel kombel. [---] Männid võeti maha Eesti iseseisvuse ajal, kui anti välja seadus, et maanteede ääred olgu lagedad. Üks jäme, tihedalt riste täis männitüve jupp lebas veel kaua maantee ääres üksinda. Muuseumi ta vist siiski ei jõudnud (RKM II 205, 384/ $9<$ Kihelkonna).

[---] varasurnud tütre rist asub Kandsimõtsa ristipedajas. Kord ôhtul tulnud ta koju - tee viib puust mööda -, näinud männikoores valendavat risti ja vallanud tundmuste tulvas kaotanud teadvuse. Silmade avanedes leidnud end maast ning näinud enda kohal valget risti. Arvanud, et on taevas ja saab peatselt tütre juurde.

[---] Teen Kandsimõtsa ristimännist fotod, riste on umbes kakskümmend. Osad on nii armistunud, et neid on raske loendada, õigemini aru saada, kas ikka on olnud rist (Marju Kõivupuu ekspeditsioonipäevikust Urvaste kihelkonda 1996. aastal).

Araku talu piirides asunud ristikuusk. Surmarongi möödumisel lõigatud iga kord kuusesse rist. Pimedas julgenud kuusest mööda minna poolnõiad ja julged. Noorpõlves läinud Luksi vanaperemees öösi kuusest mööda. Kuuse kohal olnud suur verise pääga lammas ees. Ta lugend issameiet, aga see ei aidanud. Kui Araku kukk laulma hakanud, kadunud lammas ja mees saanud koju minna (ERA II 213, 581/2 (8) < Halliste khk < Karksi khk(1939)).

[---] Seda kohta [ristipuu kohta-M. K.] kardeti õudsel kombel. Üks vigurivänt noormees tegi seal Atla naisele tonti, ise kukkus metsas hundiauku. Naine ehmatas roosi jalga, oli kaks nädalat haige (RKM II 205, 348 (93) < Kihelkonna khk (1965)). 
Naabruses asuvad ristidega puud on tekitanud mõnedel inimestel hirmuaistinguid, eriti nendel, kes on mujalt sisse rännanud ja kohalikke tavasid ei tunne.

[---] On kõhe tunne, kui rist on kodu lähedal, nigu üts kohtuotsus või nii, et miks ta sinna puu pääle om tettü (EKRK I 92, $145<$ Rõuge khk (1991)).

\section{Ristipuud ilukirjanduslikes narratiivides}

Lõuna-Eestist pärit kirjanike proosas ja luules (H. Visnapuu, Kauksi Ülle jpt) on ristide lõikamise traditsioon samuti kajastamist leidnud. Pärnumaalt pärit Peet Vallaku novellis "Relvad vastamisi", mille esmatrükk ilmus 1929. aastal samanimelises novellikogus (Vallak 1985: 77-96), jääb tekkinud armastuskolmnurgas kaotajaks Pärtel. Kaarel, kes on aasta tagasi matnud oma naise Liina, elab Pärtli naise Elluga salaelu. Saanud sellest teada, kuulutab Pärtel oma naise surnuks ja korraldab talle matused.

[---] üheksa surnut oli siit Unnustest välja viidud inimpõlve jooksul. Üks rist oli neist koguni värske: Kaarli surnud naise Liina oma [---]

Tuul kahistas ülal võimsate kaskede lehti, ja Pärtel lõi noa ühte tüvesse, et lõigata kümnendat risti. Pika riba tõmbas ta vanasse krobelisse koorde, ent siis peatus käsi ja-tõmbas noa välja.

Kas rüvetada seda vana kommet, millest seni on hoolega kinni peetud? Kas lõigata kasetüvesse kümnes rist, kui kümnendana on mööda viidud vaid tühi puusärk? [---]

Ta ei rüvetanud seda vanemate kommet, ta jättis risti siiski lõikamata (Vallak 1985: 96).

Pertti Virtaranta avaldab trükis eesti- ja soomekeelsed vestlused kirjanik Valev Uibopuuga (Virtaranta 1991). V. Uibopuu emapoolne suguvõsa on pärit Võrumaalt Kanepi kihelkonnast, isapoolne Tartuja Võrumaa piirilt Sangaste kihelkonnast Laatrest. Kirjanik ise sündis 19. oktoobril 1913 Urvaste kihelkonnas Õru metsavahi pojana ja on end nimetanud ise võrumaiseks kirjanikuks (Virtaranta 1991: 17). Vestlustes P. Virtarantaga kõneldakse ka ristipuudest Kanepi 


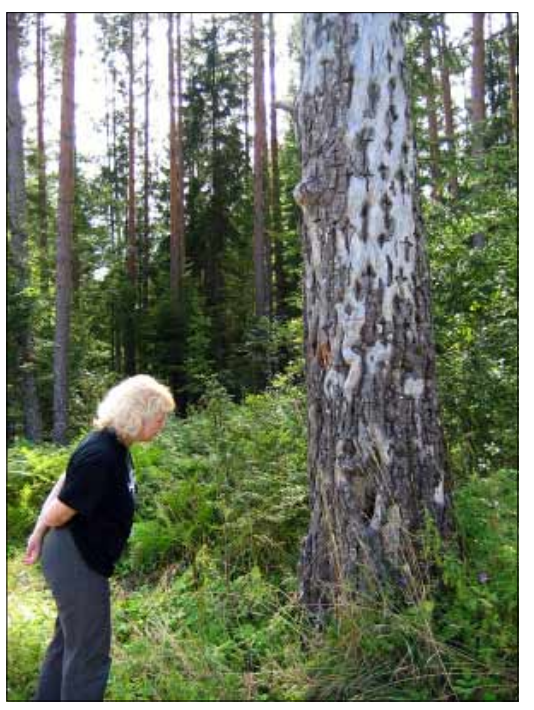

Laatre ristipedajas, august 2004. Tiit Torbi foto.

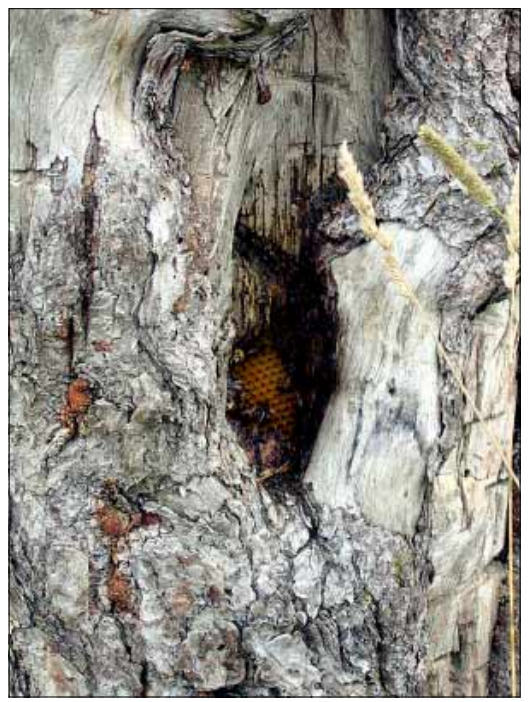

Laatre ristipedajas mesilaspesaga, august 2004. Kaarel Kõivupuu foto.

kihelkonna kirikuteel (Virtaranta 1991: 48-50). Samal teemal on V. Uibopuu mõtteid vahetanud Sarust (Hargla khk) pärit Raimond Kolgaga:

Ma kuulsin hiljem, et ka siin all Harglas - kolleeg ja sõber Raimond Kolk on rääkinud mulle - nendel oli ka siin, see on hoopis Läti piiri pääl, samasugune komme. Ja nendelgi oli ristipalu nimetus sellel metsal, ristipalu. Ta jutustas mulle üks kuu aega tagasi Stockholmis, et kirjutab just romaani, mis algab niisuguse stseeniga, nende ristide loikamise stseeniga, matustega ühenduses (Virtaranta 1991: 50).

Siinkirjutajaga samast külast pärit kirjanik Raimond Kolk (snd 1924) lahkus igaviku teele 3. novembril 1992. Kas ja kui palju jõudis ta oma plaane realiseerida, on mulle teadmata.

And last, but not least. Ristipuudel on jätkuvalt koht LõunaEesti proosakirjanduses ja luules. Üks omapärasemaid, 1970ndatel sündinud Indrek Hargla (pseudonüüm Hargla on mulle teadaolevalt võetud kodukandi kihelkonnanime järgi) naaseb jutustuses "Uskmatuse hind" (vt Hargla, Indrek. Uskmatuse hind. Algernon: Jutt. Vt 
http://obs.ee/cgi-bin/w3-msql/algernon/jutt.html?id=217) oma kodukoha põliste traditsioonide juurde, püüdes mitmetasandiliselt süveneda inimese ja puu, inimese ja metsa, inimese ja maastiku suhetesse. Ristipuu on märk maastikul ja inimese hinges ning käitumises. Ristilõikamise rituaal on tugev emotsionaalne laeng - seda nii lapse silmade läbi nähtuna ning hiljem ise rituaali sooritades.

\section{Kokkuvõtteks}

Elu ja surma piir on marginaalne. Ristipuud osana Lõuna-Eesti matusekombestikust markeerivad seda piiri nähtaval (asudes maastikul) ja vähemnähtaval (kajastudes rahvajutu repertuaaris) moel.

Metsameeste, kirikuõpetajate, ajakirjanike, kooliõpetajate ja lihtsate kohalike inimeste koondumine ühise eesmärgi nimel, säilitamaks neile nende traditsioonid ja kombed, on värvikas näide ristipuude traditsiooniga kaasuvast folklooriprotsessist meie argipäevas. Antud juhul kaasati siia ka teadlased-uurijad, et nad tekitaksid dialoogi konteksti mitte- või vähetundvate ametnikega "ülalt".

2004. aasta augusti viimastel päevadel, vahetult enne uue akadeemilise aasta algust käisin Lõuna-Eestis suguvõsa hauaplatse korrastamas ja minu tee viis mööda ka Laatre ristipedajast, Eesti teadaolevalt vanimast ristipuust, mille käekäiguga olen Mäetaguste lugejaid püüdnud kursis hoida. Minu suureks üllatuseks askeldasid kuivanud ristipuu tüveuurdes usinalt päris tavalised kodumesilased - vanast pühapuust oli selleks suveks saanud nende kodu. Just selleks suveks - valitud pesapaigas nad ilmselt talve üle ei ela liiga tuultele avatud ja liiga suur see pesaava ning oma jõududega nad seda karmide põhjatuulte eest kaitsta kindlasti ei suuda. Ometi oli selles vaatepildis midagi sümboolset, midagi liigutavat - minu kujutluses tekkisid ammu ununud seosed hingeliste ja tiivuliste vahel. Hetkeks näis, nagu oleksid kõik need lahkunud, kelle mälestusristid armistasid vana puu tüve, otsustanud end veel korraks möödakäijatele usinate mesilaste kujul ilmutada, enne kui vana puu aeg siinilmas päriselt otsa saab. 
Marju Torp-Kõivupuu

\section{Kommentaarid}

${ }^{1}$ 13. sajandil oli praeguse Eesti territooriumist umbes $50 \%$ kaetud metsaga, tänapäeval orienteeruvalt $1 / 3$.

${ }^{2}$ Loe lähemalt: Priit Kalev Parts. Milline peab olema looduskaitsealade kultuuripärandi kaitse kontseptsioon? http://www.soomaa.com/?lk=uudised \&uIDD=378.

${ }^{3}$ Lähemalt: Pärandkultuuri kaitsest metsas. http://www.hot.ee/letarand/ kaitsestmetsas.htm.

${ }^{4}$ Võru liikumise kohta loe lähemalt Võru Instituudi koduleheküljelt http://www.wi.ee/?id=18.

${ }^{5}$ Ott Heinapuu suulistel andmetel puuduvad tänastel noortel maa- ja taarausulistel matustega seotud omad rituaalid.

\section{Kasutatud käsikirjad}

E - M. J. Eiseni rahvaluulekogu, 1880-1934 ja mõned varasemad tekstid. EKRK - Tartu Ülikooli eesti kirjanduse ja rahvaluule kateedri kogu.

EKS - Eesti Kirjameeste Seltsi rahvaluulekogu, 1867-1891.

ERA - Eesti Rahvaluule Arhiivi rahvaluulekogu, põhiliselt 1927-1944, varasemad tekstid peamiselt ERA, AKs (laulualbumite kogus).

H - J. Hurda rahvaluulekogu, 1860-1906.

RKM - Eesti TA Fr. R. Kreutzwaldi nim (Riikliku) Kirjandusmuuseumi (nüüd Eesti Kirjandusmuuseumi) rahvaluule osakonna rahvaluulekogu, peamiselt alates 1945. aastast, varasemad üleskirjutused RKM, AKs (laulualbumite kogus).

\section{Kasutatud kirjandus}

Boecler, Johann Wolfgang \& Kreutzwald, Friedrich Reinhold 1854. Der Ehsten abergläubische Gebräuche, Weisen und Gewohnheiten: Mit auf Gegenwart bezüglichen Anmerkungen beleuchtet von Dr. Fr. R. Kreutzwald. St. Petersburg.

Brand, Johann Arnold von 1702. Reysen durch die Marck Brandenburg, Preussen, Churland, Liefland, Plescovien, Gross-Naugardien, Tweerien und Moscovien. Wesel: Posth.

Eisen, Matthias Johann 1918 [1920]. Esivanemate ohverdamised. Tartu: Eesti Kirjanduse Selts. 


\section{Marju Torp-Kõivupuu}

Eisen, Matthias Johann 1994. Meie jõulud. Tallinn: Olion.

Frazer 1986 = Фрезер, Джеймс. Золотая ветвь. Москва: Политиздат.

Ganander, Kristfrid 1995. Mythologia Fennica. Klaukkala: Recallmed.

Hargla, Indrek. Uskmatuse hind. Algernon:Jutt. Vt. http://obs.ee/cgi-bin/ w3-msql/algernon/jutt.html?id=217

Harju, Ülle 2004. Ristipuid piät kaitsma. Uma Leht 2 (43). Vt ka juhtkirja.

Heintalu, Aleksander (Vigala Sass) 2001. Estide(tšuudide) hingestatud Ilm: Teadaandmise raamat. Männisalu.

Hiiemäe, Mall 1995. Eesti rahvakalender VII [Rahvakombeid ja -uskumusi]. Tallinn: Eesti Raamat.

Hiiemäe, Mall \& Luts, Arved \& Pärdi, Heiki \& Troska, Gea \& Tõnurist, Igor \& Voolmaa, Aino 1993. Esivanemate varandus: Rahvateaduslik teatmik. Tartu.

Honko, Lauri. Folklooriprotsess. http://www.folklore.ee/tagused/nr6/honko.htm.

Jobes, Gertrude 1962. Dictionary of Mythology, Folklore and Symbols. New York: Scarecrow Press.

Kaasik, Ahto 2004. Hiis kui pärandmaastik. Eesti Loodus nr 7, lk 12 (292)16 (296).

Kopponen, Tapio 1973. Tietäjä: Heikki Hurstisen toiminnan tarkastelua. Helsingin yliopiston kansanrunoustieteen laitoksen toimite 4. Helsinki: Suomen Kansantietouden Tutkijain seura.

Kuidas kartul altpoolt kasvab. Jürgen Rooste intervjuu folkloristi ja surmakultuuri uurija professor Marju Torp-Kõivupuuga. Sirp 6 (2999), 13. 02.2004 .

Kulmar, Tarmo 1992. Eesti muinasusundi hingefenomenoloogiast I-III. Akadeemia nr 7, lk 1379-1392; nr 8, lk 1601-1620; nr 9, lk 1870-1887.

Kulmar, Tarmo 1994. Üldine usundilugu 1: Õppesõnastik. Tartu:Tartu Ülikooli Kirjastus.

Kriiska, Aivar \& Tvauri, Andres 2002. Eesti muinasaeg. Tallinn: Avita

Kõivupuu, Marju 1991. Minu unistuste Võrumaa. Kultuur ja Elu 10, lk 58-63.

Kõivupuu, Marju 1996. Ristipuud Lõuna-Eesti matusekombestikus. Mäetagused 1-2, lk 55-74.

Kõivupuu, Marju 1997. Ristipuud Lõuna-Eesti matusekombestikus. Akadeemia $\mathrm{nr} 1, \mathrm{lk} 35-61$.

Kõivupuu, Marju 1999. Some Archaic Traits in the Contemporary Burial Customs in Southeast Estonia. Ülo Valk (toim). Studies in Folklore and 


\section{Marju Torp-Kõivupuu}

Popular Religion 3. Papers Delivered at the Symposium "Christian Folk Religion" = Kristliku rahvausundi sümpoosioni materjale, Tartu, lk 2340.

Kõivupuu, Marju 2000a. Pulma- ja matmiskombestiku hetkeseisust. A Kiilt rahvas kynôlõs. Võrokeste keelest, kommetest, identiteedist. Võro Instituudi Toimõtiseq 8, lk 57-85. Võro: Võro Instituut.

Kõivupuu, Marju 2000b. Rahvaarstid Võrumaalt: Noor ja vana Suri Hargla kihelkonnast. Võro: Võro Instituut'.

Kõivupuu, Marju 2002. In memoriam Laatre ristipedajas. Mäetagused 16, lk 117-119.

Kõivupuu, Marju 2004. Miä om ristipuu? Uma Leht 2 (43), 3.02.

Laugaste, Eduard 1963. Eesti rahvaluuleteaduse ajalugu: Valitud tekste ja pilte. Tallinn: Eesti Riiklik Kirjastus.

Loorits, Oskar 1990. Eesti rahvausundi maailmavaade. Tallinn: Perioodika.

Lõugas, Vello \& Jüri Selirand 1989. Arheoloogiga Eestimaa teedel. Tallinn: Valgus.

Masing, Uku 1995. Eesti usund. Tartu: Ilmamaa.

Mõttus, Marilin 2001. Ristimärgiq. Mino Võromaa: Koolilatsi kirätüüq. Võru: Võro Instituut, lk 26-27.

Paulson, Ivar 1997. Vana eesti rahvausk. Tartu: Ilmamaa.

Pärandkultuuri kaitsest metsas. http://www.hot.ee/letarang/kaitsest metsas.htm

Remmel, Mari-Ann (koost) 1998. Hiie ase. Hiis eesti rahvapärimuses. Tartu.

Ränk, Arvi 1995 (koost). Etnograafia sõnaraamat. Tallinn: Ränk.

Ränk, Gustav 1996. Vana-Eesti rahvas ja kultuur. Tartu: Ilmamaa.

Saar, Evar 2004. Papa Aadami kalmuaid. Uma Leht 21 (62), 26.10.

Saareste, Andrus 1959. Eesti keele mõisteline sõnaraamat II. Dictionnaire analogique de la langue estonienne II. Stockholm: Vaba Eesti.

Sarmela, Matti 1994. Suomen perinneatlas. Suomen kansankulttuurin kartasto $2=$ Atlas of the Finnish ethnic culture 2. Suomalaisen Kirjallisuuden Seuran Toimituksia 587. Helsinki: Suomalaisen Kirjallisuuden Seura.

Simpson, Jacqueline \& Roud, Steve 2000. Dictionary of English Folklore. Oxford University Press.

Slavjanskaja mifologija $1995=$ Петрухин, В. Я. \& Агапкина, Т. А. \& Виноградова, Л. Н. \& Толстая, С. М. (toim). Славянская мифология. Энциклопедический словарь. Москва: Эллис Лак. 


\section{Marju Torp-Kõivupuu}

Torp-Kõivupuu, Marju 2003a. Ristipuude teedel. Eesti Loodus 7/8 (juuli/ august) 2003, lk 54 (362)-57 (365).

Torp-Kõivupuu; Marju 2003b. Surmakultuuri muutumine ajas: ajaloolise Võrumaa matusekombestiku näitel. Monograafia. Acta Universitatis Scientiarum Socialium et Artis Educandi Tallinnensis. A, Humaniora = Tallinna Pedagoogikaülikooli toimetised. A, Humaniora = Proceedings of the Tallinn University of Social and Educational Sciences. A, Humaniora 22. Tallinn: Tallinna Pedagoogikaülikooli Kirjastus.

Vallak, Peet 1985. Relvad vastamisi. Elu nullpunkt. Tallinn: Eesti Raamat, lk 77-96.

Viires, Ants (toim) 1995. Eesti rahvakultuuri leksikon. Tallinn: Eesti Entsüklopeediakirjastus.

Viires, Ants 2000. Puud ja inimesed: Puude osast eesti rahvuskultuuris. Tartu: Ilmamaa.

Viires, Ants (toim) 2000. Eesti rahvakultuuri leksikon. Tallinn: Eesti Entsüklopeediakirjastus.

Vilkuna, Janne 1991. Matka menneisyyteen. Konneveden Joulu 1991, lk 8-10.

Vilkuna, Janne 1992. Suomalaiset vainajien karsikot ja ristipuut: Kansatieteellinen tapatutkimus. Kansatieteellinen arkisto 39. Helsinki: Suomen Muinasmuistoyhdistys.

Virtaranta, Pertti 1991. Keskusteluja Valev Uibopuun kanssa = Vestlusi Valev Uibopuuga. Castrenianumin toimitteita 39. Helsinki.

Visnapuu, Henrik 1919. Amores. Tartu: Odamees.

Wiedemann, Johann Ferdinand 1973. Eesti-saksa sõnaraamat. Estnischdeutsches Wörterbuch. Tallinn: Valgus.

VMS = Väike murdesõnastik I 1982. Pall, Valdek (toim). Tallinn: Valgus. 